\title{
Weblog Promotes ESL Learners' Writing Autonomy
}

\author{
Maryam Foroutan \\ Department of Humanities Studies and Language Education, Faculty of Educational Studies, University Putra Malaysia, \\ 43400 UPM Serdang, Selangor, Malaysia \\ Nooreen Noordin \\ Department of Humanities Studies and Language Education, Faculty of Educational Studies, University Putra Malaysia, \\ 43400 UPM Serdang, Selangor, Malaysia \\ Mohd Sahandri Gani bin Hamzah \\ Faculty of Educational Studies, Universiti Putra Malaysia, 43400, UPM Serdang Selangor, Malaysia
}

\begin{abstract}
Today, we observe widespread application of the internet, both synchronous and asynchronous communication, by educators in many worldwide classes. Weblog (blog or web log) can be one of the instructional and integral components for ESL instructors. By applying interview and observation, this study reports on ESL students' experience and perceptions in applying weblog throughout a semester in a writing class in Malaysia. Besides, this study examined the effect of using Weblog on students' writing autonomy. The findings revealed that students enjoyed the process of publishing their writings, and exchanging their experience in the weblog. Students also acknowledged weblog as a tool which provides more opportunities to publish their writing freely, extend their interaction with their peers outside the class setting, be able to publish and share interesting videos, have the chance to look for the appropriate materials in the World Wide Web (WWW) and check their sentences in the Google simultaneously. Students enjoyed some features in weblog which cannot be found in conventional modes of teaching and learning, such as experiencing unlimited time and place, more independency and freedom in publishing and exchanging comments. With the empirical data presented in this study, weblog can be applied as a suitable instructional tool to promote autonomy among language learners.
\end{abstract}

Index Terms-ESL, computer-mediated communication (CMC), weblog, writing skills, autonomy, social interaction

\section{INTRODUCTION}

Historically, blogging began around 1993 as a forum for the National Center for Supper Computing Applications (NCSA). The term "weblog" was uttered for the first time in 1997 by an Internet enthusiast called Jorn Barger. He decided to rename his 'website' (Robot Wisdom), a 'weblog' which refers to websites that are continuously being updated (Ward, 2004). Weblogs (also known as 'web logs' or 'blogs') offer common public spaces where allow people the freedom and chance to express themselves truthfully, readily and openly (Tremayne, 2007; Barlow, 2007). Blogging is the act of posting articles- personal diaries and comments- on an online site and updating them on a regular basis (Jones, 2006). In other words, weblog is a hypertext product where one posts or publishes his/her ideas and receives comments from other correspondents in a collaborative space (Wang \& Fang, 2006). A weblog page includes the following sections: a title, a short description of the weblog, writer or author's profile, link, latter articles, new comments from readers, date and time of the post archival reports or information assorted by months, calendar and sections or subjects (Iida, 2009). Weblogs can be easily updated any time and as long as there is the Internet connection, it is available for everyone in any place for any kind of purposes including; entertainment, business, social, political issues and educational aims.

Over the past two decades, the number of weblogs in the Internet has increased dramatically. As of December 2007, an Internet search engine for tracking weblogs, Technorati, was tracking more than 112,000,000 weblogs. As more bloggers and readers are fascinated to post, read and exchange comments in the weblogs, this number has increased substantially in recent years.

Iida (2009) reported some of the reasons in using weblogs as: a) using weblogs easily: compared to websites which need specific softwares, such as Microsoft Front Page or Publisher on the users' computer, weblog needs the simplest skills, b) making personal pages with simple procedures, and, c) using weblogs with low cost: users can create their personal weblogs free of charge. Since weblogs are still new, their use for educational purposes has not been extensively discovered. The evidence on how weblogs are being applied in education and what effects they might have on students' learning, is still scarce. In most cases, teachers reported weblog's advantages for class management tasks 
including; announcement, publishing the assignments, their instruction and handouts, or putting academic calendar, so that they are easily accessible for both students and their parents (Richardson, 2006).

Through weblog, learners have the opportunity to read other learners' posts and comment or add some materials to the existing articles. This interaction makes students motivated in learning, while provides a competition for learning with other learners. Since the Internet is the only place that users can access to different sources and skills simultaneously, it is observed that students can improve their language learning (e.g., Noytim, 2010). Weblog has been reported as an excellent communication tool for small teams or groups through which students share their thoughts and work together to express their ideas collaboratively (Iida, 2009) and also an appropriate space to store data and have group work tasks (Zailin, et al., 2012). Weblog users have choice on how, when and what to publish in their weblog. They can choose the materials based on their needs and goals as well as customize their weblog any time they wish; as the result, this authority creates personalization and ownership over their ideas, writing and favorites. Ferdig and Trammell (2004) believe that bloggers can sustain motivation through this personalization and ownership. Similarly, Iida (2009) believes "learning process of exploring useful weblogs or websites according to their own needs can encourage students to develop their skills to determine which resources are necessary to use to fulfill their purposes"(p.5). Iida adds the learning process will enhance students' awareness in critical thinking through reading weblogs which are created by different users in different fields. Besides, reading the materials of these weblogs can familiarize students for their future intentions. Knowing these updated materials is crucial for digital learners as the world of knowledge is constantly changing and they are expected to move along this unstable flow of revolution. Students are expected to swim and struggle in the sea of knowledge and get the most advantage by their own efforts. As the materials are ample in CMC, students have to choose their favorite materials based on their needs. Ward (2004) asserts that "a blog provides a genuine audience, is authentically communicative, process driven, peer reviewed, provides a dis-inhibiting context and offers a completely new form with un-chartered creative potential" (p. 3.). This "dis-inhibiting" context make weblog a comfortable writing environment for bloggers to freely communicate with other peers and other bloggers and in this promising environment enhance their reading comprehension, improve writing performance and get motivation in reading and writing on other authors' posts (see for example; Arslan and Kizil, 2010; Montero-Fleta and Pérez-Sabater, 2010; Sun, 2010; Sharma and Xie, 2008; Pinkman, 2005; Ferdig and Trammell, 2004). The nature of communicative phase and learner's choice in CMC has stimulated some researchers to consider the effectiveness of CMC and weblogs in developing autonomy (Zhang, 2009; Ward, 2004; Pinkman, 2005).

\section{LITERATURE REVIEW}

\section{A. CMC and Autonomy}

In education, one of the primary perspectives in learning which has been extensively discussed is 'learner autonomy'. Researchers suggest that students who take control of their own learning can succeed greater in learning, while persist their learning for a lifetime (Little, 2007). Schwienhorst (2008) contended that learner autonomy "focuses on learnercentered approach to learning, where learners are encouraged to critically reflect on their learning process and develop a personally meaningful relation to it" (p.11). Benson \& Voller (1997) pointed out the term autonomy has been used in at least five ways:

- Situations in which learners study entirely on their own;

- A set of skills which can be learned and applied in institutional education;

- An inborn capacity which is suppressed by institutional education;

- The exercise of learners' responsibility for their own learning;

- The right of learners to determine the direction of their own learning (p.1).

There is consensus of opinions in the literature that learner autonomy emerges from the individual learner undertaking responsibility for his or her own learning (e.g., Holec, 1981; Little, 1991). The great merit of autonomy in the field of foreign and second language writing has been recently appreciated.

The challenge to facilitate EL writing and promote autonomy among learners made many educators and policy makers to look for new inventions to fulfill the problems of conventional methods. One of the widespread and prevailing methods is applying computer and the Internet in the classroom setting, as it is assumed that computers have the potential to help students to be more autonomous in learning (Schwienhorst, 2002). Boud (1988) asserts that computer could be assumed as a tool through which students have the chance to take more responsibility for their own learning.

Computer-mediated communication (CMC) has been acknowledged as the most widely used learning environment by learners, as it provides opportunity to extend their interaction and learning beyond the limitation of place and time (McAnear, 2002). Today, we observe growing number of people connect to the Internet for a variety of purposes. Some of these Internet users are learners who seek for the information on their own choice of time, place and type of materials. These flexibility in choosing the time, place and materials is believed to lead learners to autonomy in learning. Moreover, the ideal learning atmosphere for digital learners is a rich learning environment that allows and supports learners to gain knowledge collaboratively and independently, disregarding their ideal learning styles (Maesin, Mansor, Shafie, \& Nayan, 2009). 
Since digital-age learners demand an active learning experience which is social, participatory, and is fostered by rich media, curriculum is expected to cater for different students' needs; in the meanwhile encourage them to control over their learning process. The Internet and World Wide Web (WWW) are the idyllic spots for learners, especially language learners, to search for their favorite materials in their convenient time and place. By considering specific features in web-based multimedia production and distribution tools containing text (blogs, wikis, Twitter), audio (podcasting, Skype), photo (Flickr) and video (vodcasting, YouTube) which are constantly being developed and updated, McLoughlin and Lee (2010) believe that tertiary education institutions have great opportunities in integrating social media and technologies into teaching, learning and assessment.

In the modern technology, today's students are familiar with the Internet and expect to take charge of their own learning (Solomon and Schrum, 2007), while engage in the fun and interesting activities and enjoy the process of learning. Therefore, when these digital learners come across conventional learning settings, which are not customizable, they become deactivated in their learning. Layton (2000) reported some unique digital children's characteristics as; more independent, more mentally open, more patient, and more audacious compared to most 20th-century children. These children have strong points of view and expect immediate satisfaction. However, McNeely (2005) emphasized that although students have a very good command of using online tools, they might have problem in using these communication tools successfully for educational purposes. Therefore, more research is required to investigate students' perception in applying these instructional tools and to find out if students are interested and if they get the most advantage from them.

Nguyen (2008) believes that the roles of teacher as supplier and students as receivers of information have radically switched in CMC settings. Online interaction in CMC along with the constructivist principles, which emphasize the role of communication and social contacts, are important factors in developing autonomy among language learners. According to Chapelle (2001), online language learners have laid-back access to supportive tools such as: online dictionaries, word processors, and the Internet information; consequently they develop interdependency of the teacher and are persuaded to manage their own learning to a certain extent. Similarly, Knapper (1988) pointed out to the potentially promising contribution of online environment in developing lifelong learning skills, which have pivotal role in fostering learner autonomy. The online environment as mentioned by Knapper can a) offer active involvement of students in learning process; b) be manageable in time, place and degree of learning; c) suit individual differences; d) motivate students in learning as the materials are updated daily; e) allow learner's interaction and exchanging knowledge; f) encourage learners to take risk in the learning process, and g) finally allow learners to have higher control over their own learning. In addition, Tschirhart and Rigler (2009) also believe that Computer-Assisted Language Learning (CALL) has essential role in promoting learning autonomy. They further emphasized the importance of appropriate learning materials and creating the suitable learning environment in CALL context where learners can communicate and interact with other learners of the target language.

In regards to autonomy, Salmon (2000) suggested a five hierarchical model for Computer Mediated Communication. In the first stage of this model, i.e, Access level, learners will be acquainted with the technology. In the second stage, Socialisation level, learners will get involved in social interaction, exchange and communication to compare their own experience and interpret each other's ideas. In the third stage, i.e. Information Exchange level, learners exchange their ideas and knowledge with other learners and in the meanwhile develop their knowledge. In Knowledge Construction level, learners initiate working independently. Lastly, in Development level, i.e. the fifth level, learners are able to use the mode as an innovative method in learning through networking. This model has the ability to support and promote learner autonomy (Yumuk, 2002; Salmon, 2000).

\section{B. Weblog and Autonomy}

Among different internet applications, weblog enables one to many communication between the readers and writers where can freely express and exchange their ideas. Baggetun and Wasson (2006) reported on the use of weblogs to develop self-regulated learning (SRL) among students. Their finding showed that blogging supported SRL as weblog is: a) a tool to reflect ideas on a topic, b) a method to initiate conversations with other friends, and c) a mean to develop personal knowledge through others' feedbacks and other learning resources. The findings also revealed that the Internet awakened students about their metacognitive knowledge where they noticed what and whom they are communicating with. Similarly, a study by Krishnaiyer, et al (2012) showed that blog facilitated students' reflection in writing.

In the same token, Wang and Fang (2006) reported on the effectiveness of using weblog to facilitate students' skills in articulating and reflecting on their own learning, and engaging with other students. The findings of this study showed that collaborative learning through weblogs encouraged students to develop their interdependency and autonomy in groups.

Although many researchers (e.g. Chiu, 2008; Schwienhorst, 2004; Arnold, 2002; Warschauer, 1996; Beauvois, 1995) indicated a potentially promising role for technology including computer and the Internet in enhancing learner autonomy; however, there is a paucity of research on how weblogs can help language learners to promote their autonomy in learning. This study aims to begin to fill the existing gap from three perspectives. First, this research will investigate students' perception and experience on applying weblog in their learning. Second, the research will investigate how learners accept autonomy in their learning. Third, the research will test a model for applying weblog for English writing autonomy. 


\section{A Social Inquiry Teaching Model for the Web}

Social interaction is influenced by Vygotsky's (1978) "zone of proximal development" in which it is assumed this concept covers "the distance between the actual development level as determined by independent problem solving and the level of potential development as determined through problem solving under adult guidance or in collaboration with more capable peers" (p.86).

Robert A. Cole (2000) in his book 'Issues in Web-based Pedagogy' has introduced a model for applying web in teaching. He believes that web is the best teaching model in applying Vygotsky's zone of proximal development as well as a flexible multimedia communication tool that is able to integrate content presentation, interactive and collaborative communication, and research for further learning; besides, web is a creative and effective tool for students' hands-on activities. Cole further postulated that children grow through four phases of the zone of proximal development where social to psychological patterns are gradually internalized. The mentioned phases are namely: reliance on others, collaboration with others, self-reliance, and internalization. Figure 1 shows Cole's four phases of learning.

Progressing from each stage to the higher stages illustrates changing the role of students from passive to collaborative to active. On each stage, the concept of scaffolding assists the student to progress the phases from completely reliance on others (in this research is the same as dependency) to collaborative with others, to self-reliance (as we call it autonomy), and finally to internalization of the goal (which is main goal in lifelong learning) of the educational activities.

Social Inquiry Teaching Model for the Web

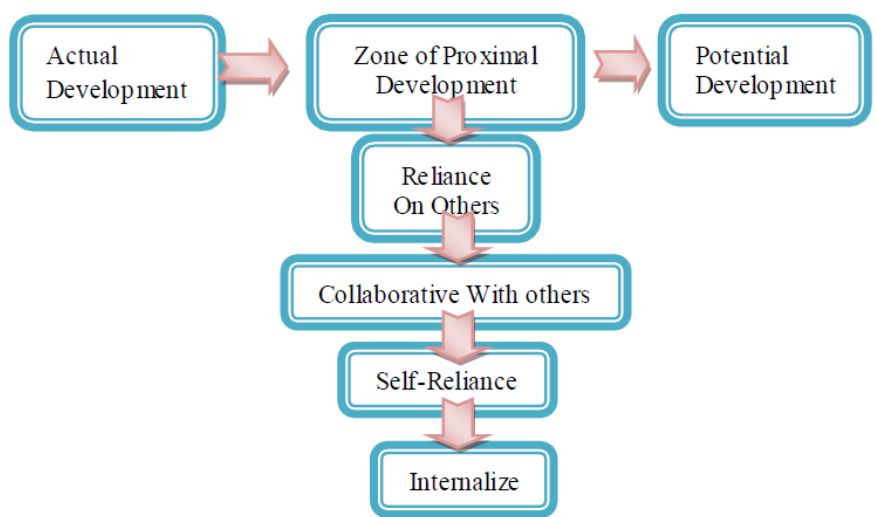

Fig. 1: Progression Through the Four Phases of the Zone of Proximal Development (adopted from Cole, 2000, p.168)

The four mentioned phases, as stated by Cole, are the basis for providing the order of instruction of a social inquiry learning model through which learners will subconsciously be acquainted with social and academic activities. Figure 2 adopted from Cole illustrates how this model can be applied for designing a website as a mediating tool that guides and scaffolds the social and inquiry-based activities of the learner through each phase of instruction.

In Cole's first phase, reliance on others, the learners are passive as they are only receivers of modeling and presentation of their teacher. In this phase, Instructional activities start when all students enter a center on the website to receive presentation prepared by the teacher. The content relates to an 'intellectual confrontation' which students are expected to challenge in finding the correct answers to academic questions. The related strategies, such as Webbing and modeling are applied in order to motivate students in their learning. Web features at this level should include multimedia components such as audio, text, video and animation to attract students' attention on the theme, content, and intellectual confrontation of the educational unit.

In the second phase, collaborative with others, learners, as inter-active learners, are able to use internal and external speech tools besides other mediating ones like the Web to enable them to communicate with mentors and construct their own potential development. In this phase, each student can enter his/her own personalized community of learning centers on the Web as Cole name these centers 'hubs'. These centers are places for learners to communicate with members of mentors in order to solve their problems and gain more information. The main features of this phase are; collaboration, interaction and communication with others. As mentioned by Cole, Web is the great tool where all these phases can be applied. Cole asserts that the activities in each hub, depending on the nature of the educational goal, should be designed in a way to include collaborative effort in which students and assistants can easily interact with each other.

In the third phase, self-reliance, students change to active learners who rely on their acquired knowledge in reflecting what they have learned and look for methods in order to gain more learning. In this phase of instruction, learners enter research centers on the Web that Cole names them 'Cubicles', initiate their own search and gather information for further learning.

In the final phase, internalization, Cole explains that students internalize their learning through repeated active application and are "capable of using their newly acquired potential development, without much conscious effort, to be creative in generating solutions to the original intellectual confrontation" (p.170). Cole pointed out that the Web has the 
potential in providing such a proper environment where students are able to have their own Web site or to become mentors for other incapable peers in on-line communities to show what they have learned and internalized.

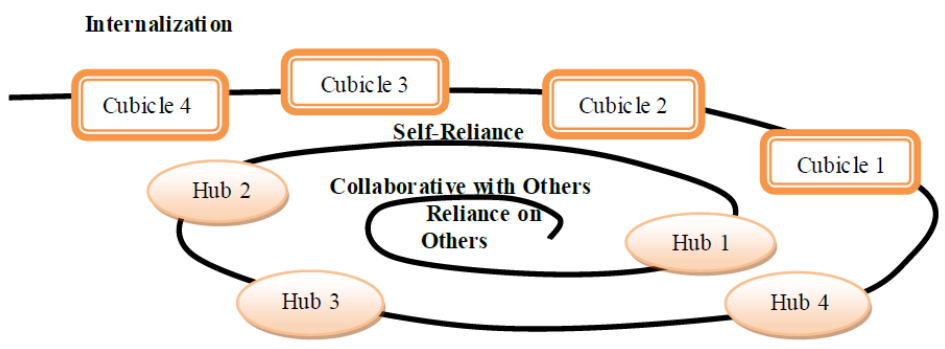

Fig. 2. Social Inquiry Model of Teaching for the Web (Cole, 2000, p.169)

\section{RESEARCH QUESTIONS}

Applying Cole's framework, this research aimed to investigate how the above framework assisted English writers to be autonomous in writing through blogging. The study addressed the following research questions:

1. What are students' experience and perceptions of using weblog?

2. What is weblog's effect on students' acceptance of responsibility in their own learning? How?

\section{RESEARCH METHOD}

\section{A. The Setting and Participants}

The participants of this research were 30 undergraduate English major students, 17 of whom were female and 13, male, from the Faculty of Educational Studies, University Putra Malaysia, Malaysia. The samples consisted of three main races in Malaysia, 16 Malay, 8 Indian and 6 Chinese. Their national language was Malay, while Mandarin and Thamil were spoken by Chinese and Indian respectively. These subjects were in their sixth semester of their studies, had taken writing courses and had intermediate writing proficiency, while their ages ranged from 22-25 years.

\section{B. Method}

Thirty undergraduate English major students who had intermediate level of writing proficiency studied at Universiti Putra Malaysia (UPM) were randomly chosen for this study. These students were asked to meet in a class (arranged by the researcher) twice a week for a 14-week period. Initially, students were given a survey in order to elicit their experience of using the Internet and blogging. Group interviews were conducted at the end of semester.

In the first session, the weblog (created by the researcher from Blogger) was introduced to the students in order to have them create their own usernames and passwords. Anonymous usernames were chosen to let students communicate and share their feeling with each other freely. Offering unlimited time and place (in or out of class), students needed to publish twenty entries at the weblog during 14-week period while selecting topics of writing was left to them. Moreover, they were requested to comment and revise each other's writings. Students were free to be logged in anytime and anywhere they wished, while teacher as a facilitator would help them upon their request.

Throughout the semester, observation helped the researcher to elicit some important information. At the end of semester, interview was conducted to gauge students' perceptions in using weblog and accepting responsibility for their own learning. Interview and observation were coded and main ideas were categorized and reported.

\section{FINDINGS}

\section{A. Students' Experience with the Internet and Weblogs}

Thirty but two students reported using the Internet every day. These students stated that the Internet was an important part of their lives. Two students reported that due to having no home Internet access, they were not able to connect to the Internet every day but twice or three times in a week at university.

Applying weblog was more limited compared to other computer applications among students. The majority of the students reported that they had not published any entries to any weblogs, except Facebook, twitter and some other popular websites. Facebook was the most popular website where students published their entries for entertainment purposes only. At the beginning of the research, the majority of students were not aware of the effect of using weblog in their learning and considered it just as a tool to entertain them in their free time. They reported they have not used weblogs but to receive and submit the assignments and also to check the curriculum calendar.

After gaining some experience with weblog, all but three students enjoyed the process of publishing their entries in the weblogs, commenting on each others' entries and receiving their peers' comments. However, three students stated to be uncomfortable with using weblog. One of them stated: 
"I think weblog is very complicated and requires specific skills, which I sometimes have problem in using these skills and feel very frustrated".

\section{B. Students' Perceptions of Advantages of Using Weblog}

All but three students reported that they had positive feelings about using weblog, mentioning that: "it was a very good experience," "I feel it is good for me to learn more", "I think I will learn better", "I can have more interaction with my friends". They reported that through weblog they were able to write more and communicate more often with their classmates. Moreover, they believed that weblog was a good medium to improve their language proficiency in reading and writing. Some students requested their partner to correct their mistakes grammatically. Students were more motivated to comment on each other's writings. Some other advantages of using weblog as reported by the students were: easier access to online bilingual dictionaries, easier correcting their sentences and spelling, and also receiving comments from their peers anytime and anywhere. Besides, students pointed out that in their previous experience of using offline tools, such as pen and paper or Microsoft word, it might have taken one week to receive their teacher's comments, while through this mode of learning, their peers could correct their mistakes within hours. This faster process made them more motivated in writing. Students acknowledged they were more interested to read and write on weblog. One student stated:

"I like to read my friend's writing and know his/her idea on a specific topic. I also cannot wait to read her/his comments on my writing. I feel using weblog is more interesting compared to writing on paper, because I can receive my comments so fast"

However, three students had negative comments about using weblog. They remarked; "I think using weblog makes me embarrassed", "I don't like my friends read my writings and laugh at me". For those two students who did not have home Internet access, communicating with their classmates outside the classroom was difficult. Interestingly, even those students who had no internet connection at home were worried about their responsibility to reply to their friend's entry. One student remarked:

"I don't have internet connection at home. It is very embarrassing for me to wait until I connect to the internet at university. I feel very uncomfortable, because I know I have to reply to my friend's writing as fast as I can".

It was observed that students were engaged to post comments on each other's entries and sustain their interaction even after class. They were aware of the effectiveness of their comments on their friend's writing proficiency. One student said:

When I receive feedback or comment from a classmate, I notice someone has read my entries and it gives me more confident and motivation to keep writing in the weblog. I like to write comments because I think my comments may help my friend to improve his/her language.

Observation also revealed that some students used Google in order to check their sentences. When one of them was asked the reason for using Google, he replied:

I use Google because I am not sure whether my sentence is correct or not. I afraid to publish something which is grammatically incorrect. I afraid my classmates laugh at me and criticize me. I think Google is the best way for me to check my sentences grammatically.

\section{Students'Acceptance of Responsibility for Their Own Learning}

Data from the interview and observation indicated that students saw weblog as a space to express their ideas freely without worrying about the limitation that often accompany traditional writing assignments. In overall, all students reported having more freedom in writing as well as more confidence to post comments on each others' entries. They liked the process of writing and posting comments due to its fast mode. It seems students were willing to receive feedback very fast instead of waiting to receive their teacher's comments one week later. Students reported that in the previous mode, i.e. offline, they were getting impatient waiting to receive their teacher's feedback, while now they were more pleased to have their writing checked online by their peers. They believed that some of their classmates were also able to correct their sentences and monitor them. Some claimed that online grammar checker and online bilingual dictionaries could assist them as a teacher could. However, some students pointed out to their peers' comments that could not be reliable. These few students insisted that their teacher correct their grammatical mistakes not any other appointees. Totally, the majority of students were satisfied in using weblog as a tool which could support them in their learning; besides they reported their willingness to keep on using weblog in their English writing class. One student claimed:

I think using online tools especially weblog is more fun compared to offline tools. We can review our writing any time we like. We can correct each other's writing easily, enjoy internet features and enjoy writing and receiving comments. I like to keep writing in the weblog and exchange ideas with my classmates.

Observation, supported students' acceptance to control over their own learning. At the beginning of the semester, since students were not familiar with the weblog application and applying the Internet as a learning assistant, more questions were asked from their teachers. However, gradually students began to establish a very good community with their peers, and their reliance from their teachers switched to their peers. It was observed that they helped each other in writing and offered some guidance in their peers' writing. To the middle of semester, students were more active in negotiating, expressing their ideas and making remarks on each other's entries. Besides, it was observed that students 
murmured with each other and checked their grammar and vocabularies. To the end of semester, they were more reliant on the online dictionaries and using Google to check their words and grammar.

\section{DisCUSSION AND CONCLUSION}

The findings of this research showed students' positive perception in applying weblog, and also students' acceptance of responsibility for their own learning. The results of this research supported Cole's framework and proved that incorporating CMC tools, including weblogs, are valuable to support language learners in promoting their autonomy. Since these online tools assist language learners to look for their own materials and correct their sentences by their own efforts; therefore, it is believed that language learner have the capacity to gradually narrow their dependency to their teacher or their peers, and consequently find themselves responsible for their own learning. As mentioned earlier, students in this study enjoyed the process of sending and receiving writings from their peers. Moreover, weblog encouraged them to continue exchanging their writings even at home where no teacher could control and force them to learn. This shows that they have relatively reached to the ultimate goal of education which makes students motivated enough in learning to control their own learning.

The role of technology as Kessler (2009) has pointed out is to provide more opportunities for language users in authentic context in which such activities stimulate students to endeavor for autonomy in the target language. The reasons for fostering autonomy among students through weblog are disclosed by Gonzalez and Louis (nd). They believe student-centered syllabus, which promote autonomy, requires defining objectives for student performance; having meaningful activities addressing students' needs, favorites and their learning styles; step-by-step lesson plan as well as an explicit evaluation method. Weblog is the best place to fulfill all these requirements. Gonzalez and Louis further indicated that through weblog, students have access to their courses at their available time and place while are able to apply metacognitive strategies to set their own objectives, manage their time, and evaluate their own performance. Likewise, McLoughlin \& Lee (2010) believe that since these social software mediums are process-based, supported and managed based on learners' interest and involvement and encourage learners to be active, they possess the potential to foster self-regulation and autonomous learning among learners.

It seems appropriate to point out that while technological innovations, including internet, bring about changes in the classroom, facilitate extensive exchanges, and encourage learner autonomy, they are ultimately tools in the hands of instructors who must utilize them creatively to maximize students' language learning. This happens by preparing and training language teachers in applying technology including computer and the internet in the classrooms. Warschauer and Meskill (2000) believe that the success in integrating technology into curriculum and getting satisfactory results rests on appropriate planning and design in how to apply it appropriately in the classes.

Limitation of the study and suggestions for further study

This research suffered from the following limitations which may lead to further studies:

- The subjects of this study were English major students who had intermediate writing proficiency. It may have affected their acceptance of autonomy. Therefore, non-English major students may get different results from this study in regards to accepting responsibility for their own learning. A further study might explore how non-English major students respond to the use of weblog in promoting their autonomy.

- The present study suggested how blog could promote students' writing autonomy. More studies are required to examine how blog can affect students' writing performance, writing process and engagement.

- Moreover, in this study, students' writing autonomy was investigated. Further study might investigate the effect of blogging on the development of autonomy in other skills.

\section{REFERENCES}

[1] Arnold, M. N. (2002). Computer-mediated communication: Writing to speak without foreign language anxiety? Published doctoral dissertation, The University of Texas, Austin.

[2] Baggetun, R. and Wasson, N. (2006). Self-regulated Learning and Open Writing. European Journal of Education 41.3/4, 453474.

[3] Barlow, A. (2007). The rise of the blogosphere. Westport, Conn: Praeger Brown.

[4] Beauvois, M. H. (1995). E-talk: Attitudes and motivation in computer-assisted classroom discussion. Computers and the Humanities 28.2, 177-190.

[5] Benson. P \&Voller. P. (1997). Autonomy and Independence in Language Learning. London: Longman, pp. 18-34.

[6] Boud, D. (1988). Developing learner autonomy in learning. Nicholas publication Company, New York.

[7] Chapelle, C. A. (2001). Computer Applications in Second Language Acquisition. Cambridge. In L.V.,Nguyen, (eds.), Computer Mediated Communication and Foreign Language Education: Pedagogical Features. International Journal of Instructional Technology \& Distance Learning 5.12.

[8] Chiu, C. Y. (2008). The discourse of an English teacher in a cyber writing course: Roles and autonomy. Asian EFL Journal $10.1,79-110$.

[9] Cole, R. A. (2000). Issues in web-based pedagogy: A critical Primer. Green Wood Press (The Greenwood educators' reference collection). Westport, CT: Greenwood Press.

[10] Ferdig, R.E., \& Trammell, K. D. (2004). Content delivery in the "Blogosphere". Technological Horizons in Education Journal $31.7,12-20$. 
[11] Gonzalez, D. and Louis, R., St. (no date). The use of Web 2.0 tools to promote learner autonomy. http://www.learnerautonomy.org/gonzalezstlouis.pdf (accessed 9/10/2011).

[12] Holec, H. (1981). Autonomy in Foreign Language Learning. Oxford: Pergamon. (First published 1979, Strasbourg: Council of Europe).

[13] Iida, A. (2009). Language Teaching Via Weblogs: Exploring New Possibilities of Teaching Japanese in JSL /JFL Contexts. The $24^{\text {th }}$ SEAJT Conference Proceedings.

[14] Jones, J. S. (2006). Blogging and ESL writing: A case study of how students responded to the use of weblogs as a pedagogical tool for the writing process approach in a community college ESL writing class. Published dissertation in partial fulfillment of the requirement for the degree of Doctor of Education. The University of Texas at Austin. Retrieved 25 September 2011, from: http:/ /repositories .lib.utexas. edu/ bitstream /handle/ 2152/ 2736/jonesd17626.pdf?sequence=2.

[15] Kessler, G. (2009). Student- initiated attention to form in wiki-based collaborative writing. Language Learning \& Technology 13.1, 79-95.

[16] Knapper, C. (1988). Technology and lifelong learning. In D. Boud (eds.), Developing student autonomy in learning (2 ${ }^{\text {nd }}$ edn). London: Kogan Page, 91-106.

[17] Layton, T. G. (2000). Digital Learning: Why tomorrow's schools must learn to let go of the past. http://metam exico.ni ng. com/ forum /topics /849670 : Topic: 9707. (accessed 13/9/2011).

[18] Little, D. (2007). Language Learner Autonomy: Some Fundamental Considerations Revisited. Innovation in Language Learning and Teaching 1.1, 14-29.

[19] Little, D. (1991). Learner Autonomy: Definitions, Issues and Problems. Dublin: Authentik.

[20] Maesin, A., Mansor, M., Shafie, A. L. \& Nayan, S. (2009). A study of collaborative learning among Malaysian undergraduates. Asian Social Science 5.7, 70-76.

[21] McAnear, A. (2002). Strategies for expanding technology's role. Learner and Leading with Technology 30. 3, 4-13.

[22] McLoughlin, C. \& Lee, M. J.W. (2010). Personlised and self-regulated learning in the Web 2.0 era: International exemplars of innovative pedagogy using social software. Australian Journal of Educational Technology 26. 1, 28-43.

[23] McNeely, G. (2005). Using technology as a learning tool, not just the cool new thing. In D. Oblinger \& J. Oblinger (2005). Educating the Net Generation. Washington, D.C.: EDUCAUSE.

[24] Montero-Fleta, B., and Pérez-Sabater, C. (2010). A research on blogging as a platform to enhance language skills. Procedia Social and Bejavioral Science 2,773-777.

[25] Nguyen, L.V. (2008). Computer mediated communication and foreign language education: pedagogical features. International Journal of Instructional Technology \& Distance Learning 5. 12, 23-44

[26] Noytim, U. (2010). Weblogs enhancing EFL students' English language learning. Procedia Social and Behavioral Sciences 2,1127-1132.

[27] Pinkman, K. (2005). Using weblogs in the foriengn language classroom: ecouraging learner independence. The JALT CALL Journal 1.1,12-24.

[28] Richardson, W. (2006). Blogs, Wikis, Podcasts, and other powerful web tools for classroms. Thousand Oaks, CA: Corwin.

[29] Salmon, G. (2000). E-moderating: the key to teaching and learning online. London: Kogan Page Ltd.

[30] Solomon, G. \& Schrum, L (2007). Web2.0: New tools, new schools. Eugene, OR: International Society for Technology in Education.

[31] Schwienhorst, K. (2008). Learner autonomy and CALL environment. New York: Routledge.

[32] Schwienhorst, K. (2004). Learner autonomy and tandem learning: Putting principles into practice in synchronous and asynchronous telecommunications environments. Computer Assisted Language Learning 16. 5, 427-433.

[33] Schwienhorst, K. (2002). Why vitrual, why environments? Implementing virtual reality concepts in Computer-Assisted Language Learning. Simulation \& Gaming 33. 2, 196-209.

[34] Sharma, P., \& Xie, Y. (2008). Student experiences of using weblogs: an exploratory study. Journal of Asynchronous Learning Networks 12. 3-4,137-156.

[35] Sithaletchemy.S., Krishnaiyer and Raja Hanani Raja Mushahar, and Nuretna Asurah Ahmad (2012). Using blogs as a tool to facilitate students' reflection. GEMA: Online Journal of Language Studies 12. 3. 939-960.

[36] Sun, C.Y. (2010). Extensive writing in foreign-language classrooms: a blogging approach. Innovations in Education and Teaching International 47.3, 327-339.

[37] Tremayne, M. (2007). Blogging, citizenship, and the future of media. London: Routledge.

[38] Tschirhart, C. and Rigler. E. (2009). LondonMet e-packs: a pragmatic approach to learner/teacher autonomy. Language Learning Journal 37.1, 71-83.

[39] Vygotsky, L. S. (1978). Mind in society. The development of higher psychological processes. Cambridge, Mass: Harvard University Press.

[40] Wang, J., \& Fang. Y. (2006). Benefits of cooperative learning in weblog networks. ERIC-ED 490815. http://www. eric. ed. Gov / PDFS /ED 49 0815.pdf. (accessed 15/2/ 2010).

[41] Ward, J.M. (2004). Blog assisted language learning (BALL): Push button published for the pupils. TEFL Web Journal 3.1, 89125.

[42] Warschauer, M. (1996). Comparing face-to-face and electronic communication in the second language classroom. CALICO Journal, 13. 2, 7-26.

[43] Warschauer, M., and Meskill, C. (2000). Technology and second language learning. In J. W. Rosenthal (Ed.), Handbook of undergraduate second language education (eds.). Mahwah, New Jersey: Lawrence Erlbaum. 303-318.

[44] Yumuk, A. (2002). Letting go of control to the learners: the role of the Internet in promoting a more autonomous view of learning in an academic translation course. Educational Research 44. 2, 141-156.

[45] Zailin Shah Yusoff, Nik Aloesnita Nik Alwi \& Ainol Haryati Ibrahim. (2012). Investigating Students' Perceptions of Using Wikis in Academic Writing. 3L; Language,Linguistics and Literature, The Southeast Asian Journal of English Language 18. 3 , 91-102 
[46] Zhang, D. (2009). The application of Blog in English Writing. Journal of Cambridge Studies 4. 1, 64-72

Maryam Foroutan is currently a PhD candidate of TESL (Teaching English as a Second Language) at Universiti Putra Malaysia (UPM). She has been an English teacher, lecturer and curriculum developer. Her areas of research interest include; applying CMC (Computer Mediated Communication) and autonomy in teaching and learning English.

Nooreen Noordin holds a doctoral degree from Universiti Putra Malaysia in the field of Teaching English as a Second Language. She was appointed as a lecturer at the Faculty of Educational Studies, Universiti Putra Malaysia. Currently, she is a TESL lecturer in the Department of Language Education and Humanities, Faculty of Educational Studies.

Mohd Sahandri Gani bin Hamzah is the Professor and Director of Educational Research Laboratory, at Sultan Idris Education University, Tanjung Malim, Malaysia. He received his Bachelor of Education in Agriculture Science from UPM (1981), Master of Education (Measurement, Evaluation and Supervision, 1995) and completed Philosophy Doctorate (Research and Evaluation of Educational Practices, 1998) from University Kebangsaan Malaysia. Besides, he is a competent and experienced professional with extensive "hands on" expertise combined with wide knowledge and skill in the area of research, planning, administration, supervision and teaching (schools, colleges and universities), versatile researcher and is active in educational consultancy. 